\title{
Katalin Fenyves
}

\section{When Sexism Meets Racism: the 1920 Numerus Clausus Law in Hungary}

\begin{abstract}
In this paper I argue that the Hungarian Numerus Clausus edict, introduced in 1920, was aimed at restricting not only the number of Hungarian Jews, but also the number of women in higher education. What is more, university admission policies, often applied beyond the legal framework of this law, reinforced and reproduced the male, nationalist, Christian and conservative hegemony. However, while the Numerus Clausus edict lived on in Hungarian common memory as the first step towards the later introduced anti-Jewish laws and the subsequent extermination of the majority of Hungarian Jews, the consequences of the law regarding women's exclusion from higher education and thus from the intellectual elite remains mainly unknown to date. Moreover, since "gendered memory" still does not exist in Hungary, there is no way to remember the introduction of the Numerus Clausus law as one of the historical moments that marked women's place and role in Hungarian society until well after the Second World War and as the symbolic moment when anti-Semitism and sexism met.
\end{abstract}

While the 1920 Numerus Clausus edict is always considered as the law that restricted the number of Hungarian Jews in higher education, the fact that it was also aimed at restricting the number of women admitted to universities and generally into the intellectual elite remains mainly unknown. Moreover, university admission policies were often applied beyond the legal framework of this law with the primary objective of reinforcing male, nationalist, Christian and conservative hegemony and thus reproducing the Christian Hungarian middle-class. While the restrictions concerning women's admission to universities remained mainly unknown even for women themselves and eventually became entirely forgotten, the Numerus Clausus edict lived on in common memory as having been antiSemitic in nature and being the first step towards later introduced anti-Jewish laws and the subsequent extermination of the majority of Hungarian Jewry. The silence about women's exclusion from higher education is especially astonishing considering that although these discriminatory policies were put into place after the First World War, they marked women's place and role in Hungarian society until well after the Second World War. However, since to date "gendered memory" does not exist in Hungary, and the history of Hungarian women remains unwritten, there is no way to remember the introduction of the Numerus Clausus law as the symbolic moment when anti-Semitism and sexism met.

When the Numerus Clausus law restricting the overall number of students who could be admitted to universities was introduced in Hungary in September of 1920, women had not been admitted to the Faculty of Medicine at the Budapest University for almost a year. While the parliamentary debate of the originally neutral Numerus Clausus bill took a decisively antiSemitic turn following extremist student demonstrations and Jew bashings, the then most influential faculty in Hungarian higher education, the Faculty of Medicine of the Budapest Pázmány Péter University, realized its old goal by introducing the numerus nullus policy for women within its own scope of authority but with ministerial approval. In my article I shall demonstrate that this encounter between anti-Semitism and sexism had a history of several decades and that the oppression of these two marginalized groups served to validate the male, nationalist and Christian conservative hegemony.

To date the infamous Numerus Clausus law (article XXV of 1920) is considered as the restriction of the access of Hungarian Jews to higher education. It is usually evaluated either as an "adjustment" aiming to correct the over-representation of Jews in Hungarian liberal professions, or as the first step on the way leading up first to later introduced anti-Jewish acts that took back the achievements of civil emancipation and then ultimately to Auschwitz. It is 
worth, however, to take into consideration the wider context of the law, while at the same time acknowledging the clearly visible issues of intellectual unemployment and the overcrowding of universities following the two lost revolutions and the shock of the Treaty of Trianon. Although almost twenty-five years ago the Hungarian law historian, Katalin N. Szegvári, analyzed the sexist aspects of the admission policies of Hungarian universities along with their anti-Semitic nature in her monograph, Numerus clausus rendelkezések az ellenforradalmi Magyarországon (Numerus Clausus: Policies in Counter-Revolutionist Hungary), this aspect of her work regarding women's oppression did not become part of the mainstream narrative dealing with the law and the subsequent policies. The Hungarian Numerus Clausus law together with its causes and consequences meant the legalization of that sociopolitical objective, which had already combined sexism and anti-Semitism in Germany and in the Austro-Hungarian Monarchy around the turn of the century, when during the social debates about the so called "Jewish question" and about women's emancipation, Hungarian opinion leaders left no doubt that only Christian Hungarian men were to lead the country and ensure the reproduction of its middle class. The nationalist and Christian conservative representatives of this objective saw gender and racial prejudices to be interchangeable; hence, alluding to the protection of the nation and its morality, they aimed to restrict the number of Jews and women in intellectual careers. The techniques of excluding Jews from powerful elite circles and public offices and women from intellectual careers were already established during Dualism starting in 1867, i.e., during the "liberal era" that is often called the golden age of the Hungarian Jewry. While the restrictions concerning women's admission to universities remained mainly unknown even for women themselves and eventually became entirely forgotten, the Numerus Clausus law along with the later introduced anti-Jewish laws and the subsequent extermination of the majority of Hungarian Jewry lived on in common memory as anti-Semitic in nature.

Similarly to Germany and Austria, in the last third of the nineteenth century, modern, racial anti-Semitism became increasingly dominant in Hungary beside the older, religiouslybased anti-Judaism. The connections between anti-feminism and anti-Semitism were already pointed out by Peter Pulzer in The Rise of Political Anti-Semitism in Germany and Austria (1964). Pulzer, similarly to most authors of historical and psychoanalytical works dealing with the relations between anti-feminism and anti-Semitism (Mosse 1966; Planert 1998; Volkov 2006; Gerö 2010), considered Otto Weininger's Sex and Character published in 1903 as one of the most influential misogynist and anti-Semitic texts of its era. Bringing together wide-spread ideas about femininity and Jewishness, Weininger succeeded in creating an "associative merger", making anti-feminism and anti-Semitism appear interchangeable.

Recent literature distinguishes between three types of sexism. Misogyny is the theory that defines woman as ontologically inferior to man, general sexism is the sum of such acts that aim to realize discrimination against women in practice and anti-feminism is the direct counter-response to the demands for equality of women, and as we shall see, examples for all three types of sexism can be found in Hungary around the turn of the century. It might not be surprising that the opinion leaders of the Catholic People's Party, founded in 1894, the most characteristically misogynist Hungarian party, opposed the emancipation of Jews just as strongly as they opposed women having intellectual careers, but liberal governments often had the same sexist and anti-Semitic tendencies as the conservatives, whose opinion leaders and publicists openly worked and called for actions against both marginalized groups. Ottokár Prohászka, for instance, one of the oft-quoted and much debated ideologists of the conservative Catholic movement, not only demanded that the government restrict the social space of Jews, but in 1908 he also participated actively in the foundation of the Szociális Missziótársulat (Mission Society, SZMT), the most significant conservative women's organization in Hungary. Although the purpose of the SZMT was to improve the social 
situation of women and to offer spiritual care, it distanced itself openly from other interconfessional and international women's organizations. Susan Zimmermann calls the representatives of this conservative trend "hierarchical integrationists", who think within a framework of hierarchical social structures, while she characterizes the members of the Feministák Egyesülete (Feminist Union, founded in 1904) as "individualist modernists" in her book, Die bessere Hälfte (1999), which though it was published in Hungary has to date not been translated into Hungarian. "Hierarchical integrationists" accept the idea of women's inferior position and that of a special female function within the existing social system, while "individual modernists" are radical in their demand for women's equal rights with men in all aspects of society. Catholic theologians accused both Jews and feminists of being selfcentered and having only their own interests in mind. In 1911, for instance, Antal Notter, professor of canon law, argued in his failed motion for the restriction of the number of women in higher education that "[feminists] have a completely individualistic perspective in so far as they view women's university studies from the perspective of their own interests and not from the perspective of the common weal" (N. Szegvári 1988, 72). Similarly, one of the recurrent elements of anti-Semitic discourse was the demand that Jews should practice "abstinence" in that they should refrain from going to university and taking the place from young Christian talents.

Remarkably, spatial metaphors were central to both anti-Semitic and anti-Feminist discourses, as representatives of both discourses talked about Jews occupying space, women "trooping" into universities, and about both minorities "invading" higher education. As I shall discuss in more detail below, the utilizing of spatial metaphors in anti-Semitic and antiFeminist discourses is especially remarkable in the light of the fact that the absolute numbers of both Jews and women in higher education were very low before World War I. Even according to the census of 1920, the overall number of professional Jews either in civil service or freelancing was only 13,826 and the number of professional women in 1928 was only 7,500 (Újvári 1929; Papp 2004).

In the light of the above low numbers, this primarily symbolic solution was provided to the very real social issues of intellectual unemployment and overcrowding of universities in 1919, when the administration of the Faculty of Medicine of the Budapest University decided against admitting women and when the ministry working on the preparation of the Numerus Clausus law approved of this policy. That is, the most prominent Hungarian university wanted to conserve the male, nationalist, Christian and conservative hegemony within the Hungarian intellectual elite. It is worth, therefore, to review the antecedents of this policy, the history of women and Jews in higher education and to recall what opinion leaders had to say about these issues in the given social and historical context of Hungary in 1920.

\section{Women in Hungarian Universities}

The emergence of women who wanted to enter higher education and have intellectual careers was not a massive social phenomenon in Hungary. Although women were employed outside the home in increasing numbers throughout the second half of the nineteenth century, this tendency continued to be perceived as unnatural by the (male) public for long into the first decades of the twentieth century. As we will see in more detail later, even the idea of women's right to free access to secondary education took several decades to be included in civil rights, resulting in that women could already attend certain faculties of universities before they were granted full access to state secondary schools, where they could learn the same curriculum as boys. Women's education and employment outside the home prompted heated social debates between the Austro-Hungarian Compromise of 1867 and the end of the World War I. Considering these debates and the underlying demographic trends, I shall 
demonstrate that the employment of women were just as much an economic necessity for women as an opportunity for individual self-fulfillment.

For the last decades of the nineteenth century due to multiple causes there was a significant increase not only in the overall number of women in Hungary, but also in the number of unmarried women who, for lack of a male breadwinner supporting them, had to work. According to demographic data cited in Katalin Kéri's monograph, Hölgyek napernyővel: Nők a dualizmus kori Magyarországon 1867-1914 (Ladies with Parasol: Women in the Dualist Hungary), while the country's population grew from 13.6 million to 18.6 million between the Compromise and World War I, some 1.2 million mostly male Hungarians emigrated overseas. As a result, the balance between the genders was overturned in certain parts of the country. In the cities this imbalance was further increased by the high number of female domestic servants, while the high mortality rate of boys was a general phenomenon. Moreover, the number of marriages was falling steadily since the end of the nineteenth century, while at the same time the number of broken marriages was also increasing due to the fact that divorce became legal in 1895. Consequently, in 1900, more than two thirds of Hungarian women over the age of 14 were not married, which most of the time meant that they had to support themselves.

After 1880, those women who were not employed as domestic servants worked mostly in chemical or food industry and in printing plants. The rate of female postal clerks, saleswomen, female typists and secretaries also started to increase as a result of the technical development, urbanization and the establishment of elementary and secondary education for girls. Between 1890 and 1900 the number of female earners increased by 14 percent; that is, their number grew by 264,190 , which meant that women made up more than one-quarter of all earners in 1900. While the rate of female workers was 25.4 percent in Hungary, their rate was 47.4 percent in Austria (probably including those women who worked on family farms or in family businesses), 29.4 percent in Norway, 29.2 percent in Belgium, 28.8 percent in Switzerland, 28.3 percent in Sweden, only 14.3 percent in the US and 14.2 in Spain, in the same year (Kéri 2008, 130). The majority of working Hungarian women was either unmarried or widow, while only 36.6 percent of them was married. Most Hungarian women, however, remained financially dependent even after the turn of the century as their number grew from 6.3 million in 1900 to 7.37 million in 1910. Indeed, women often were expected to leave their jobs immediately after marriage in order to, on the one hand, fulfill their maternal function and on the other, not to take jobs from men. Even at the end of the 1920s, professional women had to fight against the prevalent employers program and practice of the so called "female celibacy".

In 1890, the overall number of women of professional classes was $26,792,0.3$ percent of the whole female population, while the number of professional men was 155,850 in the countries of the Hungarian Crown, including Croatia and Slavonia. However, this data is misleading in as much as many of the above women of professional classes were midwives (almost ten thousand) or governesses, the latter coming mainly from abroad. A decade later, 1.5 percent of all working women had intellectual career $(33,873)$, while in 1910 , the number of professional women, along with the number of women who had completed 4, 6 or 8 classes of secondary school, increased to 3 percent $(54,726)$. Kéri also points out that although the number of educated women increased, conservative writing continued to dominate Hungarian public discourse.

When the first Hungarian female doctor, countess Vilma Hugonnai, finished her medical studies in Zurich and wanted to have her diploma naturalized in 1882, in the above described conservative public atmosphere, she had to appear before the Minister of Religion and Public Education, himself. Ágoston Trefort consulted with the medical faculty about this application, which if accepted would have meant a precedent in access to the medical 
profession for women. Although, five of the seven members of the medical faculty voted in Hugonnai's favor, Trefort, nevertheless, refused to grant her request. As Hugonnai writes, all her attempts of convincing the Minister failed because "at both hearings, his Lordship was kind enough to grant me, he emphasized that "women would upset the order of the State if they had gained emancipation' citing Russia as example" and he advised the Countess to complete a midwife training instead (Jobst 2000).

It was not an act, but only a ministerial decree that granted access to universities to women in 1895. The liberal minister, Gyula Wlassics, apprehensive of a negative outcome, did not launch a consultation on the issue in Parliament and sensing the resistance of his fellow representatives, he did not proceed with his original intentions. Wlassics's decree granted access for women only to faculties of Arts, faculties of Medicine and faculties of Pharmacy instead of to all secular faculties and declared that women's university admissions had to be evaluated by a special procedure on a case-by-case basis. In addition, Wlassics's decree denied women access to legal studies, the most prominent discipline in Hungary, which traditionally played a key role in civil service.

After women were allowed into at least some parts of higher education, the establishment of girls' high schools could not be postponed any longer. While the government had opened the three disciplines considered to be appropriate to "female roles", it had not yet established girls' high schools that could provide necessary preparatory education for university studies. Although girls could pursue high school studies as private students from 1883 on and they could sit for the school leaving exam separate from the boys in boys' high schools, only a few dozens of girls took advantage of this opportunity each year. After granting access to higher education for women, the first girls' high school was not founded by the government, but by the Országos Nöképzö Egylet (National Association for Women's Education) in 1896. This type of school immediately received sharp criticism, precisely because it filled the gap left by the government and prepared women for university studies.

In the decades before World War I, the question of women's secondary and higher education was regularly raised in Parliament. Those representatives, who opposed the establishment of girls' high schools, insisted on the conservation of the traditional female role perceived to be incompatible with both granting women access to higher education and women's employment. Imre Madarász, a protestant preacher and representative of the Independence Party (Függetlenségi Párt) expressed his opinion very clearly in one of his parliamentary speeches on why the nation's women should be warned against institutionalized education:

"I considered and consider woman to be a higher, or shall I say providential, guardian angel tending to children and husband in the sanctity of the family. In the sanctuary of the family, she is the ordained priest, the provider of warmth and nurturer of our religious and moral life. In the sanctuary of the nation, she is the unequaled preacher, teacher and fiery apostle of patriotism. Therefore I ask, whether the woman can live up to this great, glorious and noble female profession better if she earns her living in one or another career, her diploma in hand, or if she devotes all her time, all her care, all her love and life to her family, to her beloved ones as true woman and dear mother? [...] So, I only want to say that in this regard we have gone so far in our blindness, so to speak, that today we want even mothers to have a diploma, and we have gone so far in our poverty that we have to sacrifice our spirit and all the idyll, poetry, silence and happiness of our family life for our subsistence. Seeing all these, we should at least know what exactly are these girls' high schools and these higher level girls' schools which take girls of small age from their family, from the very place of their true role". (Kereszty 2010, 204) 
In 1903, at the faculty meeting of the Budapest Faculty of Arts, even liberal professors advised the university council to narrow the conditions of women's university admission as women's aspirations for higher education were considered to be only a matter of the latest fashion. Even though the minister of education did not consider this motion suitable for proposal "at this time" in his answer, until the second half of the twentieth century the only way a female could gain admission to university continued to be having received the highest possible grade on her school leaving examination, while men's grades were not a decisive factor in their university admission process even during the time of the most stringent restrictions.

In 1906-1907 the issue of women's higher education, in connection with the issue of intellectual overproduction, was on the agenda of Parliament. One of the government representatives called feminism a "contagious current" and warned against all "perverse trends" that in the name of emancipation aim to alienate women from their "true happiness". During this debate the law professor, Károly Kmety, member of the governing party, delivered his infamous speech, in which he called women who aspired to study "female monsters" and expressed his concern about the fact that the number of women students increased from 6 to 200 (N. Szegvári 1988, 71). Subsequently, although Kmety tried to explain (away) his much debated statement by clarifying that by "female monsters" he did not mean university students, only feminists, while the reality of women aspiring to be lawyers was not only that they could not graduate at the Faculty of Law of the Budapest University until 1945, but that from April 1910 they were not even permitted to attend lectures as auditors.

The First World War not only brought a sharp increase in the number of female workers, as the proportion of women working in industry increased from the pre-war number of one fifth to one third, but between 1916 and 1918 three new girls' high schools were also established in Budapest, where the majority of teachers were also women. In the last years of the war, 1,377 women attended the University of Budapest, which meant they represented 40.7 percent of the overall number of students and the 52.3 percent of the students attending the Faculty of Arts. The increase in the overall number and percentage of women in higher education met with significant resistance as the following statement demonstrates from 1917, when a professorial committee debated the then still existing restrictions of admission to faculties of arts: "because the university is first and foremost a male educational establishment [...] we need to introduce the institution of the numerus clausus." (Bihari 2008, 134)

Only after the First World War did women gain full access to higher education when on December $7^{\text {th }}, 1918$ Márton Lovászy, the Minister of Religion and Education of the Károlyi government, issued a decree that abolished all restrictions on university admission, allowing women to apply under the same conditions as men for admission to all higher educational institutions, including both the Budapest University of Technology and Economics and faculties of law. Lovászy's decree was not respected by every university, including the Budapest University of Technology and Economics. After only a year, in December 1919, the Ministry repealed the decree because it was not consolidated by the "restoration of the rule of law [that is the Hungarian Kingdom]". In August 1919, the committee of the Budapest Faculty of Medicine in its proposal of restricting women's admission to universities, on the one hand emphasized that "women have taken [...] the place of soldiers and became teaching assistants, hence they occupied the places of their male colleagues", and on the other hand, the committee stated that "[a]llowing women into medical profession has caused general disappointment as many of them have broken down physically, and some of them have broken down morally, too. In twenty years, none of them has really become a truly excellent physician" (N. Szegvári 1988, 105-06). The stance of the committee did not differ from the international practice following First World War in as much as, in 
Hungary also, those women were the most affected by unemployment who had taken the places of the now returning soldiers. The general tendency was that the more women had been employed before the war, the greater was the number of women who either were fired or had only reduced work hours after the war. Spatial metaphors like "taking the place of soldiers" or "occupying the places of their male colleagues", utilized by those who opposed women's admission to universities, demonstrate well how both the committee of the Budapest Faculty of Medicine and the press, which utilized the same rhetoric, considered women's admission to higher education to be an ultimate threat that has to be eliminated. Both argued that the inclusion of either women or Jews, whose number at the universities nearly equaled the number of Catholics in 1917, could only happen at the expense of Christian men and supported this argument by emphasizing the professional, moral and national inadequacy of both women and Jews for intellectual professions.

\section{Jewish Intellectuals and the Glass Ceiling}

While women's university admission was first granted only in 1895, Hungarian Jewish men could study at every secular or civil faculty by the bill of emancipation passed in 1867 , in the year of the Compromise. Unlike the Jacobin or American Constitution of 1793, this bill did not state that no "religious test" should be required as a qualification to any office. This difference was behind the fact that while the number of Jews in higher education was fairly high, according to the census of 1910 their number among office-holders was strikingly low: only 0.04 percent of judges, 1.2 percent of prosecutors, 2.5 percent of county administrators, 4 percent of college professors and 5.5 percent of state officials were Jewish. Compared to the overall 73,012 number of officials and other public service employees, the number of Jewish office-holders, even including the number of elementary school teachers, was only 3,841 , that is, 5.26 percent. Even though this figure is almost identical to the number of Jews in the Hungarian population $(909,500,5 \%)$, it falls far short of the incomparably higher number of Jewish university students. In the school year of 1873-74, Jewish students made up 12 percent of the total number of university students and after a continuous increase, in 1903-4 their number totaled at 30.3 percent, though this increase was followed by a slight fall.

In 1883, Ármin Neumann jr., in his analysis of the success or lack of Jewish emancipation in connection with the Tiszaeszlár trial, wrote in Egyenlöség (Equality), the leading assimilationist journal of Hungarian Jewry, that "Jews are ignored in all professions, where any effective advancement is only possible with the support of state administration." Even though Jews made up 4.5 percent of the population of the country, they were not represented in the upper house and there were only 5 Jewish representatives overall in Parliament instead of 18 that would have been in accordance with their proportion of the population. "The number of Jews working in ministries is so low, it cannot be expressed in figures, and the conditions are similar in public administration, as well, considering that the country does not have any Jewish main county administrator [Hungarian: föispán], principal clerk, attorney general, deputy county administrator [Hungarian: alispán], judge [Hungarian: szolgabíró], or mayor." According to Neumann, the situation was even worse both in the capital, where Jews made up 19.6 percent of the population, but the City Council did not have any Jewish member, and in Kolozsvár, where there was no Jewish professor among the "regular staff" of the University of Kolozsvár (Prepuk 2008, 195-96).

Memoirs of contemporary authors either published after WWI or preserved in manuscript may shed light on why the number of Jews working in public services was so low-at least those memoirs, in which the authors did not try to convince themselves of their successful integration. Apparently, Jewish intellectuals choose to believe that the reason behind the fact that it was hard enough to become teacher at a public school but it was 
impossible to become either a school principal or a university professor, was that Trefort, the liberal Minister of Education, was unwilling to promote Jews. Trefort is described in the memoir of the famous scholar, Ignác Goldziher as "the Antiochus Epiphanes of the Hungarian Jewry", referring to the ruler of the Seleucid Empire, who erected a statue of Zeus in the Temple of Jerusalem in 168 BC, or as "the Devil's priest", who dragged dozens of young Jews to the baptismal font and blasted Goldziher's hope for any promotion to university professor (Goldziher 1984, 136.). Samu Zsengeri, the first Hungarian translator of Pestalozzi, recounts a similar story in his memoir about how his own promotion to school principal was never realized. In 1885, when he met the principal of the higher girls' school of Besztercebánya, Antal Berecz, Zsengeri was neither young nor naïve. He was born in 1840 and he had already completed his doctoral exam in Humanities, when he met Berecz at a national exhibition, where the principal asked Zsengeri whether he would take the position of school principal. Since Zsengeri merely smiled, Berecz asked him, why he did not respond to the offer. Zsengeri's answer was the following: "But you know I am Jewish, why do you mock me, why do you ask such a thing?" However, Berecz's reply was that he did not ask whether he was a Jew, but whether he would take the position. After Zsengeri had discussed this offer with his wife, he was sent back and forth between public offices until he was finally told by a ministerial employee that they were waiting for his application, complete with his Certificate of Baptism. Zsengeri refused to convert, but when he told Berecz what had happened, the principal only answered that "[y]ou had to know that Trefort would never assign a position to you as a Jew" (Fenyves 2010, 193-94). The most telling example, however, is that of the academic, Bernát Munkácsi, who recounted in 1925, in Izraelita Tanügyi Értesitö (Jewish Educational Notice), how he started his career:

"[...] I had an excellent teaching qualification, a doctoral degree, great academic success, but none of these mattered to those who distributed teaching jobs and required a Certificate of Baptism. With the expression of "irregular religious status" that had come in fashion ever since Trefort became the Minister of Education, any Jewish candidate for a teaching position had to 'regularize' his religious status before he could think of working in a civil service position. But I considered this 'regularization' a heartbreaking cowardice that no prospect of a lifelong poverty could justify, no matter how my Christian friends kept on suggesting it, first innocently then with growing annoyance, as an only natural and simple request. All of my attempts at finding a job had failed, when I became a member of the Hungarian Academy of Sciences in May 1890. Sure enough, my dear friend, Béla Vikár, described my situation humorously in a poem he wrote for this occasion and published in the satirical journal Borsszem Jankó (Johnny Peppercorn): "He has a seat, but not a standing" [Hungarian: "ülése van, de állása nincs”]". (Fenyves 2010, 195)

The data published in the Hungarian Jewish Lexicon in 1929 also supports Munkácsi's recollection. Out of the 49 academics of Jewish religion or descent who were elected to the Hungarian Academy of Sciences between 1840 and 1917, 22 (45 percent) converted to Catholicism.

Apparently, the phenomenon of informal discrimination despite formal legal equality, what today would be called a 'glass ceiling', already existed in the Hungarian liberal era after the death of József Eötvös (1813-1871). Even the anti-liberal press that liked to condemn liberal ministers recognized this phenomenon: "During Trefort's reign, Jews could not move up professionally so freely [...] When Albin Csáky became the new minister of education, blissful days came for the Jews [...] Minister Wlassics surpassed even Csáky in some respect" (Petrássevich 1900, 161). However, even in 1910, more than 20 years after Trefort's death, Jews made up only 5 percent of elementary school teachers, some 6 percent of higher girls' school teachers, 12.4 percent of civil school teachers, 6.4 percent of secondary school teachers 
and only 4 percent of college professors. Although the expression of "irregular religious status" in and of itself implies that the emancipation of Jewish religion did not take place, the situation of Jewish intellectuals did not improve with the passing of the 1895 Law of Reception by which Jewish religion was officially recognized by the state either, as beside traditional religious anti-Judaism, modern racial anti-Semitism became more widespread.

As early as 1905 there was already a relative intellectual over-production. As I have argued above, this overcrowding of universities and intellectual unemployment were behind the parliamentary debate about women's higher education and it made increasingly difficult to find employment in public administration for Hungarian Jews, as well. Around 1905, even those Hungarian Jews who had good connections and came from wealthy and ennobled families had great difficulty in acquiring a position in civil service, as we can see from what director László Bánóczi wrote in the summer of 1907 to his childhood friend, György Lukács, together with whom he had formed the Thália Társaság [Thália company, a Hungarian theatrical reform movement]:

"The draftsman position is very tempting, especially if you were given the freedom as well. [...] But it is impossible for you to become an alderman [Hungarian: tanácsnok], because you would have influence over Christian, specifically Catholic issues. As far as I know, there is not a single Jew at the city [government], not even a converted one. Körössy was the only one who was able to become director, but he had already become famous all around the world by then". (Bendl 1994, 75-76)

Not long after receiving Bánóczi's letter, Lukács, once a student of the famous BudapestFasori Evangélikus Gimnázium (Fasori Lutheran Secondary School), converted to the Evangelical faith, but by then even conversion was not enough to ensure him an academic career. Similarly, in the 1910s Lajos Hatvany, five years Lukács's senior, could not achieve a political career despite his having a baronial title, having converted to Christian faith and being one of the founders and patrons of Nyugat (West) and that his father, Sándor HatvanyDeutsch was decorated with membership to the Upper House of Parliament by Franz Joseph in 1903.

Even though the main objective of the program of the Catholic People's Party, the most significant representative of the new conservative trend appearing in the mid-1890s, was to provide a greater political and economic power for the Catholic Church, the party soon began to demand a restriction on the "gruesome invasion" of the Jews. A journalist of the Party, Géza Petrássevich published figures of the number and rate of Jewish university students studying at the University of Budapest. When he compared data from 1867-68 (335 Jewish students out of the overall number of 1,885) with data from 1894-95 (1,255 Jewish students out of the overall number of 4,006), he concluded that "these awful figures demonstrate clearly the disproportionate invasion by which Jews rush into this poor university." (Petrássevich 1900, 161; emphasis mine)

Kálmán Veszprémi jr., one time Budapest journalist, also drew on statistics of Hungarian Jewish overrepresentation when he argued for a need to restrict Jewish expansion in the public sector in his study published in Debrecen in the year of his death, 1907. However, Veszprémi explained the low number of Jews in civil service not with discrimination but with their supposed greediness:

"The judges, the prosecutors, the notaries, the marshals, all of them, are only beamter [s] [German for 'civil servant']. All of them are struggling to live on the fixed salary except for the notary. But for that position, whole lines of [applicants] [...] are waiting with contacts in the right places. It is no wonder that there are so few Jews in these positions. But there is the other arm of jurisdiction, where the rule is first come 
first served and where income is only limited by the fact that a person can have only a limited number of lambs, at least at a time, since we all know that lambs can be replaced so people can be lambed down over and over again, of course, only with good reason, care and skill. And this profession is the lawyer, the unbelievable proliferation of which, we need to deal with in more detail". (Veszprémi 1907, 81)

Veszprémi relied on the same statistics of the University of Budapest as the above mentioned Petrássevich to draw similar conclusions pointing towards an alarming vision of the future:

"During the actual budget debate, Károly Hencz, alluding to these very same terrible statistics, wanted to limit the number of Jews in universities and presented a motion according to which, only a certain predetermined number of Jews could be admitted to universities. Considering this little table I really have to smile at Károly Hencz's numerus clausus. But he can set his heart at rest, because the time surely comes, when their number will not be able to go beyond 100 percent. Surely, fifty years is enough for that!" (Veszprémi 1907, 74)

During WWI, existential fears of the "happy times of peace" were replaced by modern anti-Semitism feeding on the arrival of what were perceived as uncivilized looking Galician Jewish refugees and on the unfair businesses of Jewish military millionaires. From 1916 the so called "Jewish question" was openly on the Parliament's agenda, while Jews were labeled as "truants" and accused of shrinking military service on the frontline. An increase of the number of Jewish university students in 1917-18 does, at first, indeed seem to support the above accusation, as the number of the overall Jewish population was under $6 \%$, also around these years there was also a dramatic increase in the number of women in higher education. Hence, the high number of Jews perceived as threatening, in fact, included the increased number of Jewish women, whose presence as we have seen was also perceived as threatening because of their gender. However, as I have demonstrated above, the actual numbers were not decisive for the development of these fears. Let me here refer to a caricature originally published in the journal $U^{\prime} j$ Idők (New Times) on December $20^{\text {th }}, 1896$ and which later appeared on the front-page of Orsolya Kereszty's book Nönevelés és nemzetépités Magyaroszágon 1867-1918 or the (Women's Education and Nation Building in Hungary 1867-1918) without any comment from the author. In the picture, titled "The Inauguration of the Girls' High School", a man can be seen with many negative characteristics of the stereotypical physical representation of Jews. He has a very long and very crooked nose, scruffy black hair, long gooseneck and enormous ears, while wearing black tails with a white bow tie. He is leading a lovely girl on his arm towards a door with a sign "Girls' High School." His pride is obvious and the girl's eyes are shyly and demurely downcast. That is, girls' high school education had not even started, when the conservative journal already quipped about that only wealthy Jews would take their daughters there anyway. This widespread public perception ironically was right in so far as the first women graduating in Hungary and taking up a medical, pharmacy or law career, Dr. Sarolta Sternberg, Dr. Eszter Légrády and Dr. Margit Ungár, respectively, were indeed Jewish.

\section{The Introduction of the Numerus Clausus Law}

While the board of the University of Budapest discussed the question of the admission of female students, universities were indeed so full that former students returning from military service, refugee intellectuals arriving from detached territories children of officials really could not return to or start their studies. The total number of university students in Budapest universities in 1918-19 was approximately seventeen thousand, 1,762 of which were 
women. Despite this number, decision makers found that the introduction of the Numerus Clausus law could not be postponed any longer, but its initiators originally intended it to be a policy ensuring intellectual competency and not racially, ethnically or gender based admission. In July of 1920, having just announced the Numerus Clausus bill in his government program, Prime Minister Pál Teleki, in his justification, only referred to the problem of overcrowded universities and the need to control the production of "intellectual proletariat", that is, unemployed intellectuals. However, a few days after Teleki's pronouncement, representative László Budaváry put in a motion calling for an "urgent institutional solution for the Hungarian Jewish question" suggesting the restriction of proprietary and political rights and of the rights of office and profession (N. Szegvári 1988, 116). Henceforth, the Jewish question remained on the Parliament's agenda and was kept persistently in the limelight by a new and radical right-wing political movement calling itself "awakening Hungarians" [Hungarian: "ébredő magyarok"]. During the presentation of the Numerus Clausus bill, both the expansion of Jews in intellectual careers and their proportion in universities were openly part of the debate and the bill's initiator considered the application of closed number to restrict university admission of Jews as being only "natural".

Although the text of the passed bill did not contain the term "Jew" explicitly, in its most decisive part for Jew's university admission, in the third paragraph, it said that " $\mathrm{t}] \mathrm{he}$ admission process must ensure beyond the requirements of unwavering loyalty to Hungary and impeccable moral bearing, on the one hand, that the intellectual abilities of the applicants are taken into account and, on the other hand, that the number of young people belonging to the individual races and minorities of the country among university students corresponds approximately to or reaches at any rate the nine-tenths of the proportion of these races and nationalities within Hungary" (Article XXV, Section 3 of 1920). That is, above all the text emphasized the "unwavering loyalty" to the nation and the "impeccable moral bearing" and talked about the proportion of races and nationalities, while, although in fact, Jews had been registered solely on a denominational basis in Hungary since the emancipation bill of 1867 was passed. However, no matter how vague the letter of the law, no one could entertain doubts about the real intentions of its initiators. During the parliamentary debate, several representatives cited Bishop Prohászka's book published in that same year in the Hague, where he, on one hand argued that Hungary was not ready for the reception of Jews, and on the other, as did many of his contemporaries, also called the increasing number of Jews in juridical and medical professions in the previous thirty years alarming. He particularly objected to what he called the "cultural judaization of the country", particularly in Budapest where Jews entered the middle classes too quickly and showed themselves in true unnational, alien and provocative ways. The Bishop concluded that the situation had become intolerable from the perspective of protecting national culture: "Hungary too is more than right to emphasize her own national individuality and to check all that is foreign to her" (N. Szegvári 1988, 115-16). The Piarist philosopher, Gyula Kornis, who even as late as 1925, deemed it necessary to warn against the trend of women's university education, also stated that one of the three most important tasks for the nation was the Hungarianization of the nation's intellectual class, i.e., the fight against the judaization of the Hungarian intellectual class. And since, as Kornis said, this spirit is "present in its clearest, fullest and most effective state only in Christian morality, the national and political education can only be ensured if it is pervaded by Christian religious sentiment" (Kornis 1921, 21).

Neither the Numerus Clausus bill nor the adopted law itself intending to limit the number of Jews in Universities mentioned women in any implicit or explicit way. Although during the parliamentary debate the question of women's higher education came up, representatives paid little attention to this issue. In 1920 a woman, Margit Schlachta, a member of the Keresztény Nemzeti Egyesülés Pártja (Christian National Union Party) was 
elected to the Hungarian Parliament for the first time in the history of Hungary, gaining her seat in the first district of Budapest. She was also one of the leading figures of the abovementioned hierarchical integrationist SZMT and editor of the journal Keresztény nö (Christian Woman). One cannot but wonder what was going through her mind, when during the bill's debate representative Emil Kovács outlined his thoughts on women's role in the Hungary of the 1920s in his response to national liberal (Nemzeti Szabadelvü Párt) Gábor Ugron, who had been trying to expose the disenfranchising practices of universities. Kovács said that "[i]t will turn out, when our girls and women return to the spinners and spindles even if with caution in certain regards, that we can take that good Hungarian name back not only in breadwinning but also in cloth making, which was famous of its ability to create such textiles, such garments that rivaled even Persian carpets in durability, to create such a Hungarian dress [Hungarian: díszmagyar] without any silk from Nizza that is unequalled in the world." Representative Kovács then went on to clarify the letter of the law for everyone who may have not been able to interpret it correctly: "those who do not have Christian religious morality do not have any equality in a Christian society." Kovács's talk was seconded with approval from Jenő Szabóky who shouted loudly that "[k]itchen spoon for them!" (Paksa 2010) In the end, however, the Parliament did not deem it necessary to settle the issue of female students legally, primarily because the biggest and most important university, the University of Budapest, had already taken care of it on its own by issuing severely discriminatory admission policies.

\section{The Situation of Women between the Two World Wars}

While rural universities were more tolerant in the question of admitting women since they were either newly founded or the successors of those universities that had moved from such detached territories like Bratislava and Cluj-Napoca [Hungarian: Pozsony and Kolozsvár] to Pécs and Szeged and they needed students for survival. The faculty of the University of Budapest kept rigidly aloof from this question for a time after 1919. The proportion of women in higher education reached its peak at 16.1 percent $(1,187)$ in 1916-17 before falling back to 6.7 percent (674) in 1920-21 prompting a massive lobbying campaign on the part of those women movements close to the government. The lobbying proved successful, resulting in a moderate increase in the number of women enrolled in the country's universities which in 1923 reached 9 percent. In 1927, a decree regulating women's admission to colleges was issued, which granted women full access to certain faculties and limited access to others. From this year to 1943, when the Second World War reached Hungary, the number of women in higher education remained under 15 percent. Even though the 1927 decree allowed women into Protestant and Evangelical education in theology, it denied access to legal education. Likewise, while the decree also granted women full access to pharmacy trainings, they were completely excluded from chemical engineering and mechanical engineering education. It also let women apply to the Faculty of Economics of the University of Technology and Economics without any limitation, but women could only be admitted to the architecture department if "the number of male candidates does not reach the total number of places available" and women's proportion was maximized at five percent. Women could also study at the agricultural and business departments of the Faculty of Economic Sciences without any limitation, but their number was restricted in the business school teacher training, a limitation being imposed on those who wanted teaching diplomas. Apparently, the greatest achievement was that the decree granted women full access to faculties of Medicine without any limitation within a yearly changing pre-established quota, as well as to all departments of faculties of Humanities. However, a personal letter of the committee of the Faculty of Medicine attached to the committee's report in 1929-30 well demonstrates the actual reality 
when saying that "if we accepted all candidates who had completed the school leaving exam with excellent results, 43 percent Jew and 57 percent Christian would be admitted. This figure would be approximately the same in case of admitting those with excellent and good grades" (N. Szegvári 1988, 162-63). On the basis of the data in this report, 36 female candidates had acceptable grades and should have been admitted, but under the letter of the chairman of the Selection Committee only a few of them were actually accepted.

In consequence of the continually deteriorating conditions due to the global economic crisis and the high number of university applicants, a new restrictive decree was issued in 1934. According to it, the proportion of female students was maximized at 30 percent in faculties of Medicine and faculties of Arts, 50 percent in pharmacy trainings and 30 percent in economical and business departments. This decree regulating women's number in universities remained in effect until the end of WWII.

Up to 1943, faculties of Arts had the highest proportion of female students, followed by faculties of pharmacy and the Faculty of Medicine. During the war, faculties of Arts and faculties of pharmacy kept their position, but faculties and departments of economics came up to the third place. Although a number of women attended the faculties of Protestant and Evangelical theology and the engineering departments of the University of Technology and Economics, their number remained far behind the number of male students. Throughout the period, the proportion of female students could remain constantly high only in arts colleges, in the Academy of Music (40 percent), in the Academy of Theatre Arts (50 percent) and in the Art University (30-40 percent). Accordingly, even in 1941, the overall number of women with higher education was only 12,696 in Hungary.

Even though women made their educational headway during the half century between 1895 and 1945, according to the research of Viktor Karády, the educational inequality between the two sexes lasted until the end of the 1940s. Compared to men, women were undereducated in all social classes, the quality of women's education was slow to catch up, and women suffered severe disadvantage in relation to their male peers in university admission processes. Female university students typically came from higher social classes and had better school leaving exam results than their poorer female peers, hence such relatively well educated and privileged women as Jews, Lutheran, Unitarians, Germans and other women living in urban areas made up the core of educated women. And while the situation of women with higher education on the labor market was gradually, though slowly, improving during this period, still most of them could only work in jobs that were associated with traditional female roles.

Although the Numerus Clausus Law was successful in reducing the number of Jewish students in Hungarian universities, it failed to achieve its original objective, that is, to solve the problem of reinforcing a "proportionately" Christian national middle-class. The law's symbolic significance, however, far outweighed its practical impact as it accepted restricting the rights of Hungarian Jewish citizens as "natural", hence from this perspective, it could be considered as the first anti-Jewish act in Hungary and as the immediate predecessor of the Hungarian anti-Jewish measures of the 1930s. Also, higher educational politics regarding women's admission marked women's place and role in Hungarian society until well after the Second World War. While the restrictions concerning women's admission to universities remained mainly unknown even for women themselves and eventually became entirely forgotten, the Numerus Clausus law along with the later introduced anti-Jewish laws and the subsequent extermination of the majority of Hungarian Jewry lived on in common memory as anti-Semitic in nature.

Conversations I had with my mother (born in 1918) and her peers demonstrate well that it did not matter how good their grades were, nobody thought of that they could go to university. My mother, who completed a business high school, won a national academic 
competition and wanted to become a teacher, attributed the fact that she never even thought about applying to a university to the Numerus Clausus. At the same time, her brothers both completed law school, although one of them had always wanted to become a doctor, only his application to medical school was rejected on the basis of the Numerus Clausus. Furthermore, a sculptress, around the same age as my mother and with four children, told me bitterly even at the twilight of her life that her parents did not let her study, while her less talented brother could go to secondary school. Both my mother and this sculptress seemed to be unaware of the fact that these pragmatic decisions were, in fact, the consequences of the politics of women's education of the 1930s. Maybe these missing parts of both private and common memory can account for why the findings of the great monograph of Katalin N. Szegvári have not became part of the mainstream historical narrative and why a comprehensive history of Hungarian women is unwritten to date.

\section{Works Cited}

Bendl, Júlia. 1994. Lukács Görgy élete a századfordulótól 1918-ig (The Life of György Lukács From the Turn of the Century to 1918). Budapest: Scentia Humana.

Bihari, Péter. 2008. Lövészárkok a hátországban. Középosztály, zsidókérdés, antiszemitizmus az elsö világháború Magyarországán (Tranches in the Hinterland. Middle-Class, Jewish Question, anti-Semitism in WWI Hungary). Budapest: Napvilág.

Fenyves, Katalin. 2010. Képzelt asszimiláció? Négy zsidó értelmiségi nemzedék önképe (Imagined Assimilation? Self-image of Four Generations of Jewish Intellectuals). Budapest: Corvina.

Gerő, András. 2010. Se nö, se zsidó. Elöitéletek találkozása a századforduló Monarchiájában. (Neither Woman, Nor Jew. The Confluence of Prejudices in the Austro-Hungarian Monarchy at the Turn of the Century). Budapest: Új Mandátum.

Goldziher, Ignác. 1984. Napló (Diary). Budapest: Magvető.

Jobst, Ágnes. Feb. 2000. "Emancipáció és orvoslás" (Emancipation and Medicine). Lege artis medicinae 10.2.

Kereszty, Orsolya. 2010. Nönevelés és nemzetépités Magyarországon 1867-1918 (Women’s Education in Hungary in the Era of Dualism). Budapest: Novum-Eco.

Kéri, Katalin. 2008. Hölgyek napernyővel: Nők a dualizmus kori Magyarországon 1867-1914 (Ladies with Parasol: Women in Dualist Hungary). Pécs: Pro Pannónia Kiadói Alapítvány.

Kornis, Gyula. 1925. Nők az egyetemen (Women in Universities). Budapest.

Mosse, George L. 1996. The Image of Man. The Creation of Modern Masculinity. New York: Oxford UP.

N. Szegvári, Katalin. 1988. Numerus clausus rendelkezések az ellenforradalmi Magyarországon (Numerus Clausus: Policies in the Counter-Revolutionist Hungary). Budapest: Akadémiai Kiadó.

Paksa, Rudolf. 2010. "A Numerus Clausus parlamenti vitája, 1920” (The Parliamentary Debate of the Numerus Clausus). Rubicon 4-5.

Papp, Barbara. 2004. Diplomás nök a Horthy-korszakban: A Magyar Nöi Szemle (1935-1940) (University Educated Women in the Horthy Era). Unpublished MA Thesis. Budapest: Eötvös Loránd University.

Petrássevich, Géza. 1899. Magyarország és a zsidóság (Hungary and Jewry). Budapest: Szent Gellért.

Planert, Ute. 1998. Antifeminismus im Kaiserreich. Diskurs, soziale Formation und Mentalität. Göttingen: Vandenhoeck\&Rupert.

Prepuk, Anikó. Summer 2008. "A neológ sajtó a zsidóság társadalmi befogadásáért" (The Neolog Press for the Social Integration of the Jews). Budapesti Negyed. 
Pultzer, Peter. 1964. The Rise of Political Anti-Semitism in Germany and Austria. New York: John Wiley \& Sons.

Újvári, Péter. 1929. Magyar Zsidó Lexikon (Hungarian Jewish Lexicon). Budapest.

Veszprémi, Kálmán, ifj. 1907. Magyarország és a zsidók (Hungary and the Jews). Debrecen.

Volkov, Shulamit. 2006. Germans, Jews, and Antisemites: Trials in Emancipation.

Cambridge: Cambridge UP.

Zimmermann, Susan. 1999. Die bessere Hälfte. Budapest: Napvilág. 